\title{
ResearchArticle
}

\section{Response of rice-rice cropping system to different agronomic management practices}

\author{
K. Tejeswara Rao, M.M.V. Srinivasa Rao and D. Nagarjuna
}

\section{SUMMARY}

Experiments were conducted during Kharif and Rabi seasons of 2015-16 and 2016-17 in farmers fields to study the effect of different agronomic management practices on yield and net returns of rice-rice cropping system in 2 different mandals of Srikakulam district of Andhra Pradesh. The results revealed that yields of rice-rice cropping system were significantly higher over farmer's practices, by adoption of all the recommended package of practices which includes maintenance of optimum plant population and application of recommended dose of NPK and zinc fertilizers at right stages of the crop growth to both the crops in the cropping system.

Key Words : Nutrient management, Rice-rice cropping system, Optimum population

How to cite this article : Tejeswara Rao, K., Srinivasa Rao, M.M.V. and Nagarjuna, D. (2019). Response of rice-rice cropping system to different agronomic management practices. Internat. J. Plant Sci., 14 (2): 81-83, DOI: 10.15740/HAS/IJPS/14.2/81-83, Copyright@ 2019: Hind Agri-Horticultural Society.

Article chronicle : Received : 25.02.2019; Revised : 08.06.2019; Accepted : 21.06.2019

Email : tejaseniorscientist@gmail.com

Address of the Co-authors:

M.M.V. Srinivasa Rao and D. Nagarjuna, Agricultural Research Station, Seethampeta, Srikakulam (A.P.) India 